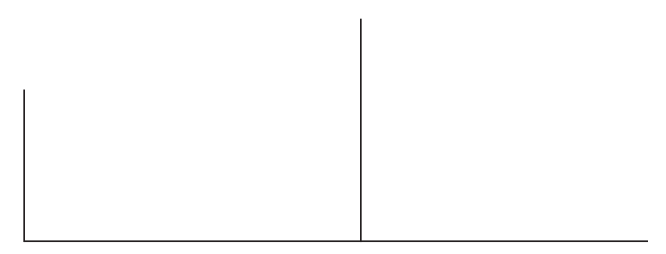

Rev. Latinoam. Psicopat. Fund., III, 4, 122-145

\title{
O início do tratamento psicanalítico com crianças autistas: transformação da técnica psicanalítica?
}

\author{
Maria Izabel Tafuri
}

Este artigo discute o início da relação analítica com crianças autistas à luz da análise de Maria, uma criança autista de três anos de idade. O caso clínico de Maria tornou-se importante como objeto de estudo, por ter suscitado um questionamento dos princípios teórico-clínicos que induzem o psicanalista a encontrar significados nas ações de uma criança autista, mesmo quando ela não fala e não brinca, $e$ a interpretá-los, desde o início de uma relação analítica, com $o$ intuito de criar a relação transferencial.

Com Maria, a analista, no início do tratamento, deixou em suspenso os significados e as interpretações e passou a vivenciar a natureza fenomenal dos "grunhidos" $e$ "maneirismos" da criança. Ao proceder dessa forma, abriu-se uma outra via para se criar uma relação analítica com Maria: as várias tonalidades e ritmos dos seus "grunhidos", o zumbido de seus "maneirismos", as formas dos seus movimentos corporais e o ritmo da sua respiração, passaram a ser contidos pela analista em seu próprio corpo, contudo, esse material clínico não foi interpretado no início do tratamento de Maria.

Palavras-chave: Psicanálise, autismo, interpretação, significados 


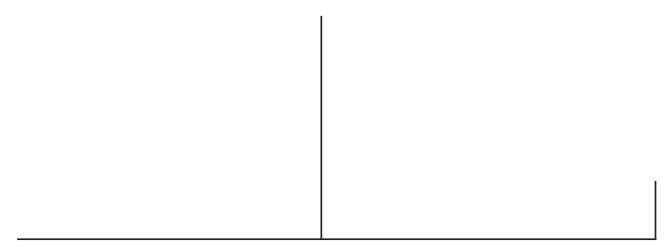

\section{Introdução}

Este artigo discute o início da relação analítica com crianças autistas à luz da análise de Maria, uma criança autista de três anos de idade. $\mathrm{O}$ caso clínico de Maria tornou-se importante como objeto de estudo por ter suscitado um questionamento dos princípios teórico-clínicos que induzem o psicanalista a encontrar significados nas ações de uma criança autista, mesmo quando ela não fala e não brinca, e a interpretá-los, no início de uma relação analítica.

Os princípios da interpretação aparecem claramente em três casos clínicos de crianças autistas, já consagrados na literatura psicanalítica: o caso de Dick, publicado por Melanie Klein, em 1930; o de John, analisado por Frances Tustin, em 1972; e o de Halil, recentemente descrito por LaznikPenot, em 1997. Essas analistas encontraram sentido ou um valor significante, a ser interpretado ou traduzido pelo psicanalista, em qualquer produção de uma criança autista, seja a produção gestual ou sonora. As interpretações, guardando as diferenças entre as autoras, estiveram presentes desde o início da relação analítica com seus pequenos pacientes, Dick, John e Halil, e continham um objetivo central: o de criar a relação transferencial com as crianças.

Com a pequena Maria, a analista, no início do tratamento, deixou em suspenso os significados e as interpretações e passou a vivenciar a natureza fenomenal dos "grunhidos" (sons congelados, sem a sonoridade da voz humana) e "maneirismos" da criança. Ao proceder dessa forma, abriu-se uma outra via para se criar a relação analítica com Maria: as várias tonalidades e ritmos dos seus "grunhidos", o zumbido de seus "maneirismos", as formas e os ritmos dos movimentos do seu corpo e o ritmo da sua respiração passaram a ser utilizados e reproduzidos pela analista em seu próprio corpo, sem contudo interpretá-los. Ou seja, sentir a presença de Maria no próprio corpo foi, para a analista, o fio condutor do trabalho analítico 


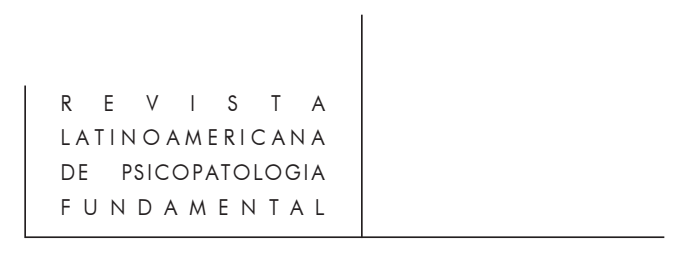

com essa pequena criança. Em uma etapa posterior da análise, quando Maria começou a jogar, balbuciar e desenhar; as interpretações tornaram-se presentes e continuaram sendo empregadas ao longo do tratamento.

Em síntese, a partir do caso de Maria, concluiu-se que, desde o início do tratamento, "os grunhidos e os maneirismos" das crianças autistas podem ser compreendidos e usados pelo analista em sua natureza fenomenal, como sons, ritmos, movimentos e singularidades, e não como uma mensagem dirigida ao analista, a ser por ele interpretada ou traduzida.

O artigo está dividido como se segue: começa com uma discussão dos três casos clínicos de crianças autistas já mencionados, seguidos da apresentação do caso clínico de Maria para, ao final, discutir a técnica utilizada no início do tratamento dessa menina. A descrição dessa técnica é o ponto central do artigo.

\section{A análise de três crianças autistas: Dick, John e Halil}

Melanie Klein publicou, em 1930, o caso clínico de uma jovem criança chamada Dick, encaminhada aos seus cuidados com o diagnóstico de demência precoce. Dick tinha quatro anos,

... era carente de afetos e indiferente à presença ou ausência de sua mãe... estavam quase completamente ausentes a adaptação à realidade e as relações emocionais com seu ambiente (... ) não tinha interesse pelos brinquedos (a não ser um interesse muito específico pelos trens, estações, maçanetas e portas) (...) não brincava e não tinha contato com o seu ambiente. Na maior parte do tempo, articulava sons ininteligíveis, e repetia constantemente certos ruídos; quando falava, utilizava erroneamente seu escasso vocabulário (Klein, 1930: 298-299).

Para Klein, o pequeno garoto era diferente de todas as outras crianças que ela já havia tratado (somente muitos anos depois, Dick foi diagnosticado como autista).

Na primeira sessão, Dick acompanhou a analista, sem demonstrar nenhuma angústia ao se separar da babá. No consultório, não se interessou pelos brinquedos: ficou correndo de um lado para outro, sem qualquer propósito. Klein assim descreveu o seu sentimento inicial: “... ele correu em volta de mim como se eu fosse um móvel; a expressão de seus olhos e de seu rosto era fixa, ausente e de desinteresse (...) e não tinha relação com nenhum afeto ou angústia" (ibid.: 302)

O obstáculo fundamental para o começo da análise de Dick foi, segundo a analista, sua falta de interesse pelo ambiente e a ausência de relação simbólica com as coisas. Segundo Klein, como o pequeno Dick não brincava e não tinha capacidade para se expressar verbalmente, o material para análise deveria ser “... extraído do simbolismo revelado por detalhes do seu comportamento em geral" (ibid.: 302). 


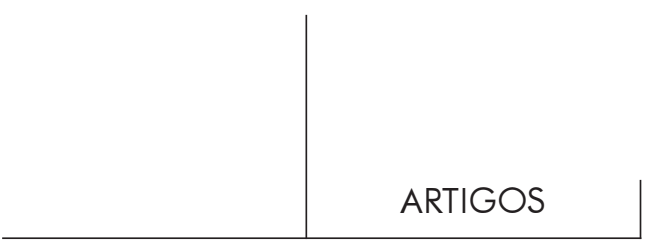

Klein criou, inicialmente, um jogo a ser compartilhado com Dick. Pegou dois trens e disse que o maior era o "trem-papai", o outro, o "trem-Dick". A pequena criança pegou o trem que levava seu nome, levou-o até a janela e disse: estação. Klein assim interpretou Dick: "a estação é a mamãe; Dick está entrando na mamãe". Após essa interpretação, Dick largou o trem e se escondeu atrás da porta e disse: escuro. Klein novamente interpretou: "está escuro dentro da mamãe, Dick está entrando na mamãe escura". Outras interpretações foram realizadas nessa primeira sessão...

Já na terceira sessão de tratamento, Klein relatou os primeiros sinais de angústia e dependência de Dick. Naquela oportunidade, Dick demonstrou ansiedade ao deixar a babá e entrar no consultório, e também ao sair, quando a abraçou de forma afetiva. Segundo Klein, justamente quando se deu essa expressão de afetividade, Dick passou a se interessar pelas palavras tranqüilizadoras e pelos brinquedos. A partir dos sinais de surgimento de angústia, decorrente da relação afetiva com a babá e com a analista, como também do interesse pelos brinquedos, Klein relatou ter ultrapassado o obstáculo fundamental da análise de Dick. E, assim, podia continuar analisando aquele pequeno por meio da técnica do jogo, como fazia com as demais crianças em sua clínica.

A técnica do jogo foi descrita por Melanie Klein, em 1932, no seu primeiro livro, The Psychoanalysis of Children, que marcou, segundo Hanna Segal (1973), o apogeu da primeira fase de sua obra. Klein acreditou ter tornado plenamente viável uma efetiva análise infantil com o uso da interpretação da relação transferencial, desde o início do tratamento. Essa concepção era oposta às idéias de Anna Freud.

Klein enfatizava o contato com o inconsciente, a ser realizado com as crianças pela via da interpretação da transferência e do conteúdo simbólico do jogo, desde o início do tratamento psicanalítico. Segundo ela, um dos primeiros efeitos da interpretação no tratamento seria o alívio da angústia e o aparecimento das fantasias, que conduzem a novas angústias a serem interpretadas. Trata-se, assim, de um circuito que, considerado do ponto de vista quantitativo, é reduzido e permite o conhecimento progressivo da realidade pela criança (Klein, 1921, 1932, 1955).

Em resumo, com Dick, Klein realizou uma transformação da técnica psicanalítica, tendo em vista a ausência da linguagem lúdica da criança. Ela propôs, para o início do tratamento, um jogo simbólico (o "carro-pai" e o "carro-Dick ") visando criar uma relação analítica com o pequeno garoto e tornar possível a análise, tal como fazia com as outras crianças tratadas por ela. Ou seja, se o pequeno paciente não trouxe, a princípio, o material clínico usual à interpretação (o jogo e a transferência), Klein se incumbiu de apresentar o jogo simbólico à criança: uma inversão de papéis, em que a analista propôs o jogo simbólico a ser seguido pelo pequeno paciente. Nesse sentido, o princípio teórico-clínico deixado por Klein, em sua clínica com as crianças autistas, foi o de criar um jogo simbólico (com base nos 
conhecimentos teóricos do analista) para propiciar as interpretações usuais e criar a relação transferencial com o pequeno paciente, no início do tratamento.

Na década de 1960, Frances Tustin, psicanalista inglesa de formação kleiniana, iniciou sua clínica com crianças autistas com o garoto John, quando ele tinha três anos e sete meses. Em seu primeiro livro, Autism and Childhood Psychosis, publicado em 1972, a autora assim descreveu o caso de John na primeira sessão de tratamento:

John intrigou-me com sua quase total ausência e qualquer forma de expressão: passou por mim como se eu não existisse e só no consultório deu mostras de algo um pouco diferente, quando me puxou a mão para o pião, que pus a girar. (...) John corou violentamente, inclinou-se todo para frente a olhá-lo, ao mesmo tempo em que rodava o pênis por cima da calça e com a outra mão fazia movimentos circulares à volta da boca - quase um girar. Essa seqüência me fez imediatamente suspeitar de que era tênue a diferença que estabelecia entre os movimentos do pião e os de seu próprio corpo, o que, com a excitação sensual, apaixonada mesmo, que dele se desprendia, me fez concluir que essa seria importante no trabalho futuro, para que eu tentasse manter o clima analítico e interpretasse, se quisesse vê-lo conseguir gradualmente distinguir-me de suas ilusões primitivas e ajudá-lo, dessa forma, a chegar a um acordo com os sentimentos provocados pela desilusão (Tustin, 1975: 16-17).

Tustin relatou que utilizava poucas palavras para interpretar o pequeno John e que repetia várias vezes a mesma interpretação, às vezes acompanhadas por gestos. Na nona sessão com John, Tustin, ao observar que o garoto utilizava repetidamente o pião, interpretou: “... ele estava usando sua mão para fazer girar o pião Tustin, porque queria sentir que John seria Tustin e Tustin seria John. Então poderia sentir que ficaríamos sempre juntos" (ibid.: 18). Em uma outra situação, John retirou uma boneca que representava a mãe e começou a girar a conta que servia de fecho à carteira na qual ela apoiava a mão, fazendo um movimento em tudo semelhante ao de rodar o pênis. Depois ele a jogou no chão, dizendo: "embora". Tustin, então, fez nova interpretação: "John girava a conta da mamã como se fosse o xixi dele, para sentir que podia ir direitinho para dentro da carteira da mamã, mas isso o fazia sentir que a mamã era "embora" (ibid.: 19).

A partir do caso de John, Tustin criticou a teoria de Melanie Klein:

... os enunciados extraídos de minha formação kleiniana ortodoxa, que tão bons serviços me haviam prestado no trabalho com outros pacientes, não constituíam um marco adequado para os fenômenos que me eram apresentados no trabalho com crianças autistas (Tustin, 1990: 97).

Tustin se referia à noção de "buraco negro" trazida por John. Essa noção era, para a autora, uma sensação dolorosa de separação entre John e sua mãe. 


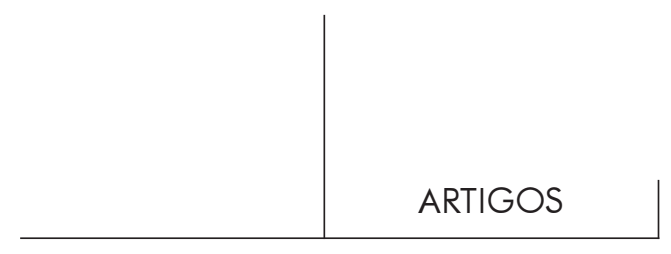

É importante perceber isto para entender o autismo, porque aí dominam as sensações de separação. Quando eles têm a sensação de que estão separados da mãe é extremamente doloroso. E é tão doloroso que eles podem não ter representação, como você diz, no eu mental (Entrevista de F. Tustin a E. Vidal, 1995: 88).

Tustin não encontrou dentro do referencial kleiniano uma forma para explicar o "buraco negro". Segundo ela, "a idéia de objeto de Melanie Klein preenche demais o 'buraco'; o autismo é uma objeção ao objeto kleiniano” (ibid.: 89).

Em 1990, ao publicar El cascarón protector em niños y adultos, Frances Tustin caracterizou o início do tratamento psicanalítico da criança autista como o do uso das interpretações das "figuras de sensações". Essas interpretações têm o objetivo de levar a criança a estabelecer "... nexos mentais com um terapeuta vivenciado pela criança, como uma mãe nutridora. A isto chamamos transferência infantil" (Tustin, 1990: 131).

Segundo Tustin, a relação transferencial é criada por meio das interpretações "dos objetos e figuras autistas", com dominância sensorial. Na opinião dela, retirar a criança autista do isolamento sensorial patológico, em que ela se encontra, constitui o primeiro e o maior desafio para o psicanalista.

Tustin diferenciou a clínica psicanalítica com crianças autistas daquela com crianças psicóticas, limítrofes ou neuróticas, da seguinte forma:

À diferença das crianças do tipo esquizofrênico, as autistas não se encontram emaranhadas em estados de identificação projetiva. Não estão "identificadas" com a mãe; se sentem grudadas a ela e igualadas com ela, o que exclui toda sensação de encontrar-se separadas. Chamo isto de "identificação adesiva" como outros autores têm denominado de "fusão imitativa" (Gaddini, 1969). As crianças reelaboram estes sentimentos na relação com o terapeuta” (Tustin, 1990: 85).

Em suma, o princípio teórico-clínico que norteou o trabalho de Tustin, quanto ao tratamento psicanalítico das crianças autistas, foi a noção da "interpretação das figuras e objetos autistas", em oposição à técnica kleiniana da "interpretação do jogo". Apesar das novas idéias, ainda continuou prevalecendo, para Tustin, o princípio psicanalítico de Klein, quanto à necessidade de se criar a relação transferencial a partir da "interpretação", apenas com outra forma: "a interpretação das figuras e dos objetos autistas". Ou seja, a necessidade de se conferir sentido aos comportamentos bizarros das crianças autistas, desde o início do tratamento, continuou presente na obra de Tustin, à semelhança de Klein. A criança autista, desde o seu encontro inaugural com o psicanalista, está irremediavelmente submetida a uma rede de significados, simbólicos (Klein) ou de sensações (Tustin). Mais ainda, as interpretações oriundas do jogo das fantasias ou das sensações são imprescindíveis para que a clínica psicanalítica possa operar. 
Na década de 1990, Marie-Christine Laznik-Penot, psicanalista lacaniana, admitiu que

... o trabalho com uma criança autista se faz ao avesso da cura analítica clássica: o objetivo do analista não é o de interpretar os fantasmas de um sujeito no inconsciente já constituído, mas o de permitir o advento do sujeito. Faz-se aqui intérprete, no sentido de tradutor de língua estrangeira e, ao mesmo tempo, tradutor em relação à criança e aos pais (1997: 11).

Ao fazer essa proposição, Laznik-Penot trouxe uma outra transformação da técnica: no lugar da "interpretação do jogo de Klein" e da "interpretação das figuras e objetos autistas de Tustin", apresentou a "técnica de tradução", dirigida à criança e aos pais, desde o início do tratamento psicanalítico com as crianças autistas.

Já possuindo experiência com criança autista estrangeira, Laznik-Penot recebeu para tratamento psicanalítico o pequeno Halil, um garoto turco com quase dois anos de idade. Com ele, pôde vivenciar o "quanto este laço exclusivo com a língua do analista vinha separá-lo das fontes vivas dos significantes de seu ambiente familiar" (ibid.: 14).

Halil já apresentava um quadro nítido de autismo infantil, apesar de sua tenra idade, conforme descrição da analista:

Ele não apenas não emitia nenhum chamamento, nem respondia, como também seus olhos estavam sempre baixos, e seu olhar, muito oblíquo, quase nunca encontrava alguém. Podia ficar por muito tempo deitado no chão, em um canto, contemplando seus dedos e suas mãos (ibid.: p. 14).

O enquadre do tratamento de Halil foi distinto daquele no qual Dick e John foram inseridos. Laznik-Penot recebia não apenas a criança, mas também os pais dela. Em sessões conjuntas com Halil e sua mãe, três vezes por semana, a autora também tinha a companhia de uma residente, a dra. Marie-Annick Seneschal, encarregada por anotar tudo nas sessões. As anotações dessa senhora, segundo Laznik-Penot, foram importantes não apenas para permitir a transcrição das sessões, como também para ajudar a analista a reter os enunciados da mãe de Halil, realizados em uma outra língua: “... tinha necessidade de um indício dos significantes da mãe e da criança que, logo, começou a proferir palavras - uma, duas, por vezes três, em uma sessão" (ibid.: 16).

Nos quatro primeiros meses do tratamento de Halil, Laznik-Penot observou que ele sempre pegava, do armário, um brinquedo de encaixe com peças de plástico. Ele também fazia muito barulho com a porta metálica do armário. Quando assim procedia, sua mãe ficava com raiva e dizia: "Anne atta", o que significa, "mamãe vai embora". Essa cena se repetiu várias vezes.

Um certo dia, depois de fazer o barulho costumeiro, Halil escolheu um brinquedo de encaixe com peças de plástico. Ele o sacudiu e as peças se soltaram. A 


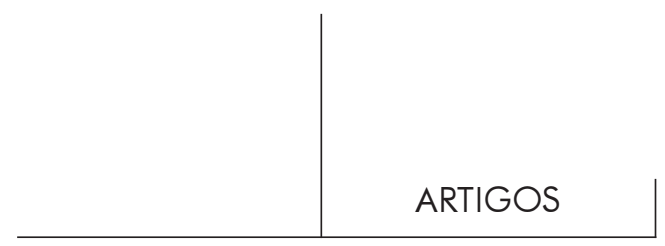

mãe retirou o brinquedo das mãos dele e os atarraxou com força para que as peças não se soltassem mais - as peças eram presas por um parafuso. Halil começou a protestar, jogando vários objetos no chão. A mãe retirou a caixa de brinquedos de perto dele, quando, então, Halil avançou para bater na analista e na mãe. Naquele momento, Laznik-Penot traduziu os motivos da raiva de Halil para a mãe: "Trata-se de uma tentativa de representar a separação, uma separação que não destrói, já que é possível reencontrar-se, como as duas peças do brinquedo que podem se desparafusar e se parafusar" (ibid.: 18). A mãe passou a aceitar melhor o comportamento de Halil, ao ver sentido naquelas ações.

Halil ficou muito triste depois da intervenção da analista e se escondeu dentro do armário de brinquedos, "em um estado de desarvoramento autístico muito rápido" (ibid.: 18). Ali, deitado, dentro do armário, a analista o ouviu dizer: "Dede", o que a mãe traduziu por vovô.

Baseando-se em suas experiências, Laznik-Penot concluiu que o trabalho de "tradução dos comportamentos do filho" para a mãe foi de importância fundamental para restituir a ela "a loucura necessária das mães" (conceito de Winnicott referente à capacidade das mães em conferir significado aos comportamentos iniciais do bebê). Conforme palavras de Laznik-Penot: "No trabalho com o analista, a maioria das mães reencontra rapidamente esta capacidade" (ibid.: 21). Esse trabalho de "tradução" permitiu também, segundo a analista, que a criança começasse a brincar nos primeiros meses do tratamento. Para Laznik-Penot, a ação de Halil, de separar as peças do brinquedo de plástico e falar algumas palavras, caracterizou o jogo em seu sentido mais radical, de "trabalho do pensamento". O brinquedo de plástico foi utilizado por Halil como um instrumento adequado para pensar a separação, concluiu a analista.

Em síntese, ao descrever o caso do garoto Halil, Laznik-Penot apresentou uma outra modificação da técnica psicanalítica para o tratamento de crianças autistas, a saber: "a técnica da tradução", dirigida para a criança autista acompanhada de sua mãe. Essa técnica, empregada no início do trabalho psicanalítico, teve o intuito não apenas de criar a relação transferencial entre a criança e a analista, mas também permitir à mãe compreender suas angústias em relação ao filho e a si mesma.

O princípio básico psicanalítico de Klein, o de encontrar sentido em qualquer produção da criança, persistiu no caso de Halil, contudo com uma outra modalidade de interpretação: “... o analista antecipa o sujeito a vir, ao interpretar qualquer produção como um ato colocado pela criança para tentar advir a uma ordem simbólica que lhe preexiste" (ibid.: 11).

Conforme se observa, as técnicas apresentadas por Melanie Klein, Frances Tustin e Marie-Christine Laznik-Penot, para serem usadas na fase inicial do tratamento psicanalítico com crianças autistas, partem de um pressuposto básico: deve haver, desde o início, a interpretação - ferramenta clássica da clínica psicanalítica. Esse 


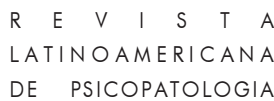

procedimento deve ocorrer segundo a concepção tradicional, tanto em relação às crianças quanto aos adolescentes e adultos, nas diversas patologias.

Apesar das transformações propostas por Tustin e Laznik-Penot às idéias de Klein, a interpretação, seja das "figuras das sensações e objetos autistas" seja das "traduções", continuou a ser utilizada no início do tratamento da criança autista, com o intuito de possibilitar o surgimento do brincar, das fantasias, das associações livres e da transferência.

Diferentemente dos casos relatados pelas três analistas, a experiência clínica com Maria, a seguir relatada, vem de encontro a esse pressuposto básico: a necessidade elou a possibilidade do uso da interpretação nos primórdios do tratamento de uma criança autista.

\section{Os primórdios da relação analítica com Maria}

Maria, uma criança de três anos, foi encaminhada à minha clínica com o diagnóstico psiquiátrico de autismo infantil precoce.

Quando os pais chegaram para a primeira consulta, ela entrou correndo na ponta dos pés, sem olhar para nada. A mãe a segurou e disse: "ela não fica parada, tem muita energia". Os pais se sentaram e Maria continuou correndo pela sala, sem explorar os objetos e sem nos dirigir o olhar. Enquanto os pais contavam a história de vida de Maria, ela emitia grunhidos e girava as mãos em frente ao seu rosto, com muita velocidade e leveza. Ela parecia hipnotizada com o movimento das próprias mãos. As pontas dos seus pés tocavam o chão, com muita leveza e agilidade, dando a impressão de não carregarem o peso do corpo da menina.

Maria retirava rapidamente todos os brinquedos da estante, não os explorava e os deixava cair de suas mãos como se escorressem pelos dedos. Ela andava sobre os brinquedos caídos no chão, como se nada atrapalhasse o seu equilíbrio. Maria não havia demonstrado angústia ao entrar no consultório e parecia não me ver. Os seus olhos passavam pelos objetos sem nenhuma intenção de exploração, a não ser quando fazia as rodas de alguns carrinhos girarem. Nesse momento, parecia envolvida com o movimento circular das rodas, sentava-se no chão, balançava o seu corpo em torno de si mesma e "grunhia".

Nessa primeira sessão, conversei com os pais de Maria sobre a história de vida deles, tanto do casal quando da criança, com o objetivo de compreender a maneira como os pais se sentiam em relação aos sintomas de Maria.

À luz dos ensinamentos de Françoise Dolto e Maud Mannoni, das quais recebi minhas primeiras supervisões clínicas, estabeleci um contrato de trabalho: os pais viriam no início do tratamento, uma vez por semana, para conversarmos sobre Maria e sobre eles mesmos (a análise da relação transferencial analista-pais-criança 


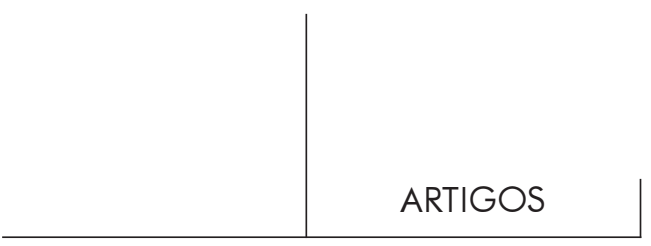

possibilitou o prosseguimento, com êxito, do tratamento de Maria, no entanto, o trabalho analítico realizado com os pais não será detalhado neste trabalho, pois o ponto central aqui desenvolvido se refere ao início da relação analítica com a pequena).

\section{O início do tratamento psicanalítico com Maria}

Maria começou a ser tratada três vezes por semana, em sessões individuais. Nos dois primeiros meses, permaneceu completamente isolada. Quase sempre, ela entrava correndo no consultório, na ponta dos pés, fazendo estereotipias com as mãos, sem demonstrar angústia por deixar a mãe na sala de espera do consultório. Agia como se eu não estivesse ali. Retirava todos os brinquedos do armário, como na primeira sessão, e corria sobre eles na ponta dos pés. Com seu corpo franzino, e agindo ligeiro, não tocava em quase nada. Ela não pegava os objetos para explorá-los ou colocá-los na boca, apenas os tocava e os deixava escorrer pelos dedos. Maria não se encostava nas paredes, não se sentava nas poltronas e nem no divã. No banheiro, ela abria a torneira da pia com frequiência e espalhava água por toda parte. Ao seu comportamento no banheiro, eu comecei a impor limites: fechava a torneira sempre que ela abria de novo. Maria não impedia minhas ações e nem ficava irritada.

Nas sessões iniciais com Maria, o que mais me chamou a atenção foi o estado de excitação exibido por ela quando "grunhia e balançava as mãos em frente ao seu rosto". Nesses momentos, Maria parecia hipnotizada pelas próprias mãos: balançava o corpo para frente e para trás em um ritmo cadenciado e emitia sons fortes, estridentes, atonais e arrítmicos. Não se pode dizer que eram gritos de raiva ou expressão de alguma necessidade. Os sons não surgiam em associação a qualquer gesto ou mímica facial. Eram totalmente anárquicos e desprovidos de significado emocional. Na realidade, eram sons que brotavam de sua boca com uma sonoridade específica: eram metalizados, como que congelados, havendo uma ausência da sonoridade da voz humana.

As primeiras considerações que me vieram à mente foram as de que os "grunhidos" eram "figuras de sensação" (Tustin, 1990) e que talvez pudessem ser interpretados com o objetivo de levar a criança a sair do seu estado de isolamento. Havia um comportamento em Maria que me chamava a atenção: quando "grunhia", ela ficava em contato extasiado com seu próprio corpo. Ao mesmo tempo em que girava as mãos na altura de seus olhos, ela balançava o corpo em torno de si mesma, "grunhia" e só olhava as mãos, como que hipnotizada. Como definiu Tustin, “... as figuras de sensação apaziguam e acalmam, e por conseqüência, essas figuras são um tipo de tranquiilizante gerado com o próprio corpo" (ibid.: 117). As "figuras de sensação" são criadas, segundo Tustin, com os movimentos estereotipados das 


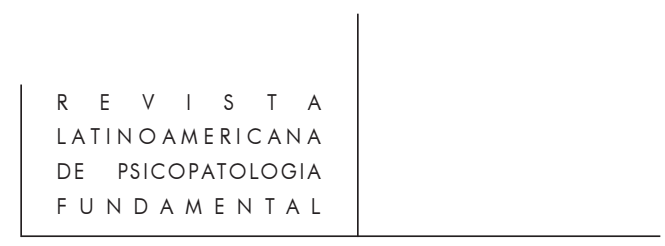

mãos e do corpo. Elas são engendradas sobre a superfície do corpo, não têm relação com os objetos externos, são idiossincráticas e não compartilhadas com as outras pessoas.

Pensei em interpretar o sentido dessas sensações para Maria, como propõe Frances Tustin, mas fui tomada por um questionamento: será que eu não estava pensando de forma estanque e rápida uma criança que eu ainda não conhecia? Ficava assustada com a forma pronta como os pensamentos me vinham à mente quando estava com Maria. Era inevitável a comparação desse meu comportamento com o trabalho realizado com crianças que brincam e falam. Com crianças normais, eu podia esperar, nas primeiras sessões, que desenhassem, me contassem estórias e brincassem. Assim, a partir do material simbólico e da relação transferencial existente, podia interpretá-las à luz da teoria.

Com Maria, ao contrário, os pensamentos advindos da teoria me vinham de pronto, quase automatizados. Poderia, talvez, dar início à interpretação. No entanto, interpretar "os grunhidos e os maneirismos" dela como "figuras de sensação", me pareceu o mesmo que começar a analisar crianças, que falam e brincam, antes mesmo que elas possam jogar ou contar suas próprias estórias. Essa conclusão me fazia ficar calada e vivenciar, mais um pouco, o que Maria estava me levando a sentir e pensar. Ou seja, me pareceu necessário esperar mais e deixar em suspenso os conceitos clássicos que vinham de forma rápida e estanque à minha mente.

Decidi então vivenciar os "grunhidos" de Maria, imitando-os, para tentar ocupar minha mente com os sons e as sensações advindas daquela criança ainda desconhecida. Essa atitude me fez experimentar a sensação dramática de isolamento existente entre nós: era impossível imitá-la: os "grunhidos" de Maria tinham uma tonalidade distinta dos sons que eu podia reproduzir; era como tentar falar uma língua estrangeira sem sotaque. Ou seja, eu não tinha como experimentar os sons de seus "grunhidos", fazia apenas aproximações. Desse fato, surgiu a seguinte constatação: lá onde eu não podia estar, onde os sons eram somente de Maria, era o lugar onde ela existia, em seu estado de isolamento autístico. Parecia um lugar criado por ela e só para ela.

Baseando-se nessa constatação, procurei, cada vez mais, compreender as minhas sensações, sem necessariamente interpretá-las para a criança. Isto porque a minha sensação de isolamento, surgida em meu corpo quando tentei imitá-la, tinha uma conotação distinta daquela proposta pela literatura que trata de crianças autistas.

A definição de "figuras de sensação" foi útil para classificar e nomear o que eu observava em Maria. Mas, ao me deparar com a vivência da impossibilidade de imitá-la, percebi que, como analista, eu ocupava um outro lugar. Não o lugar do intérprete ou do tradutor, mas "o lugar da impossibilidade" de traduzir ou inter- 


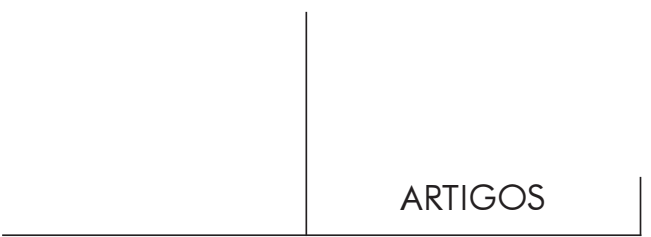

pretar uma vivência para a criança. A partir desse “outro lugar”, foi iniciada minha relação com Maria.

As sessões ocorriam sempre no mesmo horário e nos mesmos dias da semana, e eu me redobrava em cuidados para manter a mesma aparência física e a mesma organização do consultório.

No início do tratamento, minhas ações consistiram, como mencionado, em emitir sons parecidos com os "grunhidos" de Maria, com o intuito de senti-los em mim mesma, e, a partir desse sentir, proporcionar uma oportunidade para que algo de novo pudesse surgir na relação analítica com a criança. As repetições dos sons, utilizadas no lugar das interpretações, só eram realizadas nos momentos em que Maria apresentava um estado de isolamento autístico, no qual parecia hipnotizada pelos "grunhidos e maneirismos das mãos e do corpo". Nesses momentos, Maria ficava mais absorvida com as sensações oriundas de seu corpo; deixava de correr pela sala e parava de jogar as coisas no chão. Os sons de seus "grunhidos" eram menos estridentes; "os maneirismos das mãos" pareciam ser contemplados por ela, e os movimentos do corpo eram ritmados. Ou seja, ela balançava o corpo para frente e para trás, em um ritmo cadenciado, como se estivesse sentada em uma cadeira de balanço invisível. Nesses momentos, considerava importante apenas repetir os sons de seus "grunhidos", para de alguma forma diferenciar o estado de absorção completa das sensações do corpo dos outros comportamentos estereotipados, como os de correr, abrir e fechar a torneira da pia do banheiro, jogar brinquedos no chão etc.

No final do terceiro mês de tratamento, Maria começou a entrar em estado de angústia sem que eu pudesse compreender a origem deles. Foi uma novidade dentro do contexto analítico, pois, até então, as sessões eram preenchidas apenas pelos outros dois estados de sensações descritos acima. Maria começava a se morder ou bater a cabeça na parede, de forma repentina, tanto no estado de isolamento em que se deixava absorver por completo por suas sensações corporais, quanto no outro estado de sensações, em que ela parecia ansiosa correndo de um lado para outro, jogando objetos pelo chão.

Quando Maria entrava em angústia, eu a segurava de costas, afastava seus braços de sua boca e evitava o contato olho a olho. Maria tentava se soltar, mordia meus braços e dava cabeçadas em meu peito. Era uma ação física, sem palavras. Nesses momentos, os "grunhidos" desapareciam e ela passava a "urrar". Não eram gritos, nem choro, eram "urros" de sonoridade grave. Os sons dos "urros" eram mais próximos da sonoridade humana. Então, Maria saía de um estado de sensação preenchido pelos "grunhidos" e passava, repentinamente, para um outro estado de sensação, preenchido por uma angústia dolorosa e sofrida.

Quando eu segurava Maria, sentia o peso de suas costas inquietas, que me machucavam. Elas se encaixavam no meu tórax e abdome, de tal forma ser possí- 


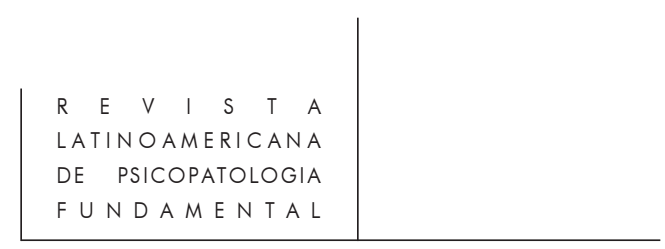

vel escutar as batidas rápidas do meu coração e o dela. Era como se os dois estivessem em um mesmo corpo. Nós duas ficávamos ofegantes e com os corações disparados. Eu sentia também a rigidez do seu corpo contra o meu. Era muito peculiar a sensação: não se tratava de um rechaço, como a birra de uma criança que se debate para desgrudar da pessoa que a segura; ao contrário, parecia que eu estava segurando um pedaço de carne pesada e disforme. Maria não se aconchegava no meu corpo, não se consolava e não me olhava. Em meio a essas manifestações, eu também me sentia profundamente angustiada e sem palavras para traduzir o seu sofrimento.

O pulso esquerdo de Maria estava sempre em carne viva por causa de suas freqüentes mordidas. Ela não movia um músculo do rosto para expressar dor, nem mesmo quando mordia o mesmo lugar, o que me causava uma grande estranheza. Eu me peguei várias vezes fazendo gestos de dor e segurando a respiração para não chorar. Era como expressar a dor que ela não demonstrava. Eu me sentia como se estivesse dentro de um turbilhão de sensações confusas, provocadas pelo corpo de Maria e o meu.

Nos momentos de angústia, os sons emitidos por Maria denotavam sofrimento, um sofrimento não suportado pelo seu próprio corpo; ela parecia não sentir dor. É um sentimento impensável, como Bion (1962) e Winnicott (1952) descreveram. Esses dois autores trouxeram os conceitos de "analista continente" e holding, que podem ser aplicados a essa situação. Segundo eles, a mãe pode conter as crises e excitações do bebê e transformá-las em experiências suportáveis, a partir da capacidade de rêverie da mãe. Para Bion (1960), muitos pacientes necessitam que o analista contenha os sentimentos que eles mesmos não conseguem suportar, para depois transformá-los por meio das interpretações.

Em uma fase posterior do tratamento, surgiu um comportamento diferente em Maria. Ela começou a passar as costas das mãos nas paredes assim que eu terminava de emitir os sons. Parecia que tentava localizar os sons que ouvia no espaço do consultório. Como também poderia estar experimentando sensações táteis advindas dos sons ("alucinações táteis", Aulagnier, 1985). Maria não passava as mãos pelas paredes da sala quando ela proferia os sons, mas assim agia somente se os sons eram meus.

Observei também alguns novos comportamentos bem característicos em Maria: ela só passava as mãos pelas paredes quando não estava em angústia ou quando estava "grunhindo". Também parou de balançar as mãos em frente aos seus olhos enquanto "grunhia"; em vez disso, passava as costas das mãos nas paredes, após ouvir os sons que vinham de um outro lugar.

Após algum tempo de repetições incansáveis desses comportamentos (quase dois meses), Maria começou a se interessar pela origem dos sons que ouvia. Esse interesse fez com que ela encontrasse partes do meu corpo, usando o toque das mãos. Maria começou a olhar para a minha boca, assim que eu acabava de proferir 


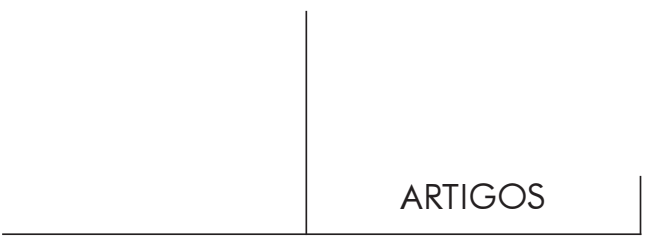

os sons. Ela batia as costas das mãos nas paredes e ia se aproximando da minha boca, porém sem me dirigir o olhar. Era como se eu fosse apenas boca. Assim como fazia nas paredes, começou a passar as costas das mãos em minha boca. Às vezes, me mordia, ou chutava, sem que eu tivesse tempo de prever tais manifestações de angústia. Quando isso acontecia, eu me silenciava, parava de emitir sons, respirava profundamente e ficava quieta. Essa minha reação corporal permitia a ela recomeçar a emitir os sons.

O surgimento da capacidade de espera: início das interpretações

No final dos sete primeiros meses, Maria começou a demonstrar que estava esperando por alguma coisa: ela "grunhia", interrompia e ficava quieta. Arriscava alguns olhares fugidios, de forma periférica, isto é, fazendo estrabismos. Após ouvir os sons emitidos por mim, começava a "grunhir" novamente. No início, a espera era permeada por crises de angústia, nos quais começava a gritar e a se debater, jogando a cabeça contra a parede, antes e durante as minhas imitações; um tipo de vivência extremamente difícil de relatar, pois não se tratava de aplacar uma angústia engendrada por uma frustração passível de ser nomeada. Era uma ameaça de aniquilamento, uma interrupção do senso de um "continuum" de existência, a meu ver inominável.

Nessa fase do tratamento, as crises de angústia, que surgiam inesperadamente, começaram a ficar mais localizadas no intervalo entre a interrupção dos seus "grunhidos" e a espera dos meus sons. À medida que as crises de angústia foram se repetindo em uma seqüência de atos, pude começar a imaginar as sensações de Maria.

A capacidade incipiente de Maria em esperar por algo foi para mim um marco importante na relação analítica com ela, pois, a partir daí, pude imaginar as suas sensações e prever, com uma certa margem de segurança, o que ela iria fazer em seguida. O mais fundamental nas repetições da angústia foi o surgimento da minha possibilidade de imaginar as sensações de Maria, e, assim, a possibilidade de interpretá-las. Por exemplo, em todas as sessões, ela tentava imprimir a mesma rotina de ações. Ou seja, ela chegava, jogava os brinquedos no chão, começava a "grunhir" e a esperar pelos meus sons. Quando algo impedia a sequiência de suas ações, Maria entrava em angústia, seguida de um estado de isolamento autístico, preenchido pelos "maneirismos e grunhidos idiossincráticos". Quando eu identificava os motivos da angústia, eu os interpretava. Contudo, nem sempre era possível compreender a origem das angústias e, nesse caso, eu ficava calada, procurava respirar profunda e pausadamente, não olhava para os olhos dela e lentamente ia começando a emitir os sons usuais dos grunhidos de Maria. Dessa forma, ela voltava à seqüiência de suas ações. 


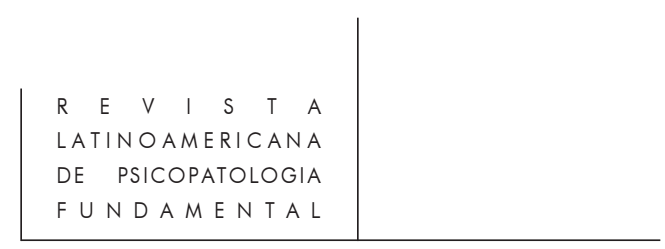

Tanto as interpretações verbais, quanto as minhas ações corporais de ficar em silêncio, respirar ritmicamente e emitir os sons dos "grunhidos", davam condições a Maria de continuar a sua sequiência ações. Nessa fase do tratamento em que Maria esperava pelos meus sons e encostava as mãos em minha boca, as suas sensações de contentamento e de desilusão eram mais visíveis. As desilusões eram acompanhadas pelo isolamento autístico. Os estados de angústia eram mais caracterizados, ou seja, ocorriam depois de ela ter visto ou ouvido algo que trouxesse desilusão. Isto é, Maria respondia de forma diferenciada a escuta dos sons, que ela, inclusive, começara a esperar. Ou ela continuava a seqüência prevista ou a interrompia com respostas de angústia. As interpretações lhe permitiam voltar às seqüências e ela novamente entrava em angústia.

Nessa fase, considerei que o tratamento de Maria já começara a se enquadrar nos princípios da técnica psicanalítica da interpretação do brincar, apesar de não haver ainda uma representação simbólica por meio dos desenhos ou da fala. Ela introduziu modificações no ritmo dos sons e na modulação da voz. Posteriormente, começou a balbuciar. Paralelamente ao surgimento dos balbucios, Maria começou a explorar os brinquedos. Ficou caracterizado o que denominei de "jogo dos balbucios": Maria começava as sessões balbuciando sem olhar para mim. Em seguida, derrubava uma caixa de bonecos, depois uma de animais de plástico e, por último, a do lego. Então começava a balbuciar novamente, se escondia pelos cantos da sala e se calava. Eu começava a balbuciar como ela (nessas repetições eu já não me sentia isolada, pois os balbucios eram sonoros e ritmados, como os de um bebê), que então saía dos seus "esconderijos", me olhava e gritava alegremente. Depois se voltava para os brinquedos e começava a explorá-los, passando-os pela boca, pelo seu corpo e pelo meu. Posteriormente, ela passou a ficar mais tempo escondida até que eu me aproximasse e a encontrasse. Do lugar onde estava escondida, ela esperava, com prazer, ouvir a minha voz. No momento do encontro ela me abraçava afetivamente.

Essa brincadeira, criada por ela mesma, tinha uma carga afetiva intensa: ela sorria, gritava e pulava nas pontas dos pés, fazendo estereotipias com as mãos. As estereotipias, como o pular nas pontas dos pés e o balançar das mãos na frente do rosto, passaram a surgir apenas nessas manifestações afetivas. Houve também uma contextualização dos comportamentos estereotipados e eles deixaram de ocorrer isoladamente. Nessa fase, eu comecei a me esconder para repetir os sons de Maria e, dessa forma, ela começou a me procurar e a se encostar junto ao meu corpo.

Aos poucos, ela foi podendo olhar para o meu rosto, começando aí a exploração do meu corpo: ela pegava nos meus lábios, boca, nariz e garganta, como se quisesse entrar neles; também passava sua língua em meu rosto, em minhas mãos e braços. Não eram raras as mordidas e as manifestações de angústia, em meio a 


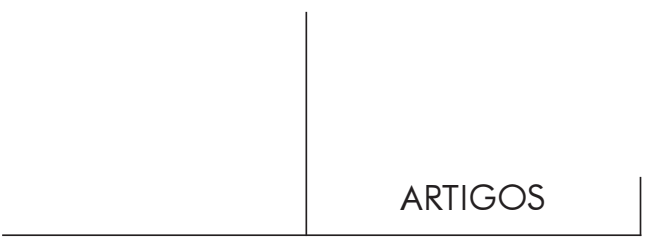

essas explorações corporais. Contudo, após as mordidas, ela passava as mãos sobre as marcas das mordidas no meu braço e se aconchegava no meu colo, aninhando-se como uma criancinha.

Os brinquedos que ficavam em cima do armário começaram a ser apontados por ela, acompanhados de um olhar para mim. Ali, começou a ficar presente uma designação, a possibilidade de apontar algo. Primeiramente com os olhos e depois com o dedo indicador.

Posteriormente, ela começou a se interessar por estórias de contos de fadas. Em especial, a do Chapeuzinho Vermelho. Ela me "pedia" para contar a estória, pegando o livro e levando até onde eu estava. Eu lia a estória, reproduzindo as vozes dos personagens. Ela me olhava como se precisasse se certificar que eu estava ali, principalmente quando eu fazia a voz do lobo mau. Às vezes, ela jogava o livro no chão e me olhava amedrontada, como se eu fosse o lobo mau. Eu interrompia a estória e dizia: "eu estou aqui, você está com medo que eu me transforme no lobo mau". Ela me dava as costas e sentava no meu colo. Eu a abraçava calada e ficávamos ouvindo e sentindo os nossos corpos.

No terceiro ano de tratamento, Maria começou a fazer as primeiras garatujas e a falar as primeiras palavras. Os pais me contaram que ela estava ficando mais manhosa para se separar deles e já não dava as mãos a qualquer pessoa. Agora, ela tinha reações de angústia em presença de estranhos e estava mais afetiva com os pais e professoras. Também os desenhos evoluíram rapidamente e, por meio deles, ela começou a representar suas angústias. Nessa fase, eu interpretava seus desenhos, estórias e sonhos na relação transferencial com Maria. Contudo, quando ela entrava em quadro de muita angústia, parava de falar, e eu também. Às vezes, em uma mesma sessão, eu tanto interpretava os desenhos, quanto começava a imitar seus sons, se assim ela demandasse.

Maria começou a ler e a escrever sem que ninguém a ensinasse e passou a freqüentar escola comum, nas séries correspondentes à sua idade cronológica. Eu prestava orientações à escola e às professoras, visando facilitar a adaptação dela. Maria conseguiu terminar o primeiro grau enquanto estava em tratamento comigo. Tive notícias de que continua a estudar, está interessada em namorar e quer fazer vestibular para medicina. Enfim, leva uma vida normal.

\section{Conclusão}

Quando comparado aos casos clínicos de Dick, John e Halil, o início do tratamento psicanalítico de Maria ficou marcado por uma transformação da técnica proposta por Klein, Tustin e Laznik-Penot. No caso de Maria, não foram utilizadas interpretações. Nem a interpretação do jogo (Klein), nem a interpretação das figuras de sensação (Tustin) e nem a tradução dos significantes (Laznik-Penot). 


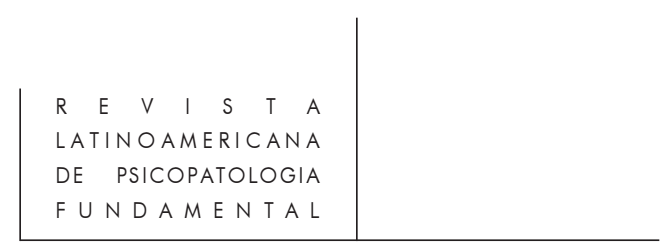

Este fato ocorreu por não ter sido possível encontrar palavras para interpretar os significados dos "grunhidos e maneirismos", que eram quase as únicas manifestações de Maria, na fase inicial de seu tratamento.

A vivência com Maria foi marcada, no princípio, pela impossibilidade de imitar os sons dos seus "grunhidos", e não pela emergência, na mente da analista, dos sentidos ou significados de suas ações. Diferentemente de Klein, Tustin e LaznikPenot, eu, como analista, me senti no lugar daquele que não tem nada a interpretar. Em outras palavras, ficara vazio o lugar do analista para ser o intérprete do brincar simbólico (Klein) ou do analista intérprete das "figuras de sensações" (Tustin) ou, ainda, o lugar do analista "tradutor de língua estrangeira" (Laznik-Penot). Com Maria, me senti em um outro lugar, no lugar de não ter palavras para interpretar.

$\mathrm{Na}$ etapa inicial do tratamento, os significados que surgiam em minha mente não vinham da relação com Maria. Muito ao contrário, vinham dos meus conhecimentos gerais sobre os casos de outras crianças. Tendo em vista essa peculiaridade, optei por esperar o surgimento de um material clínico mais genuíno, isto é, advindo da própria criança.

A partir da espera da emergência de um material clínico advindo de Maria, comecei a vivenciar um outro tipo de encontro com aquela frágil criança. Uma vivência marcada pela não mediação da palavra, em que os significados ficaram suspensos. Esse fato me permitiu observar a singularidade dos sons, dos ritmos e dos movimentos corporais de Maria e, ao mesmo tempo, reconhecer em mim mesma a singularidade da tonalidade e do ritmo dos "grunhidos e maneirismos" dela.

Nessa etapa inicial do tratamento, o desafio foi conseguir ouvir a apresentação direta de Maria, isto é, vivenciar seus "grunhidos e maneirismos", a partir de uma relação não mediada pela palavra. Essa atitude ocorreu, não apenas porque as representações simbólicas estavam ausentes, mas também porque os "grunhidos e maneirismos" não foram ouvidos e entendidos como uma linguagem pré-simbólica dirigida a mim, como propõe Laznik-Penot (1997: 10-15):

... o analista assume, então, por momentos, o lugar do Outro primordial. Mas ele também antecipa o sujeito a vir, ao interpretar qualquer produção como um ato colocado pela criança para tentar advir a uma ordem simbólica que lhe preexiste (...) tinha, ainda, como analista, um outro trabalho a fazer: tentar decifrar com a criança - no sentido de encontrar um cifra, um código - um determinado número de vividos afetivos, os quais, por nunca terem sido ligados a representações de palavras, tinham sobre ela um efeito destrutivo, como um puro real de uma descarga motora.

Para Tustin, os comportamentos repetitivos de John, como "fazer girar o pião e balançar o corpo em torno de si mesmo", foram considerados dentro do referencial simbólico: 


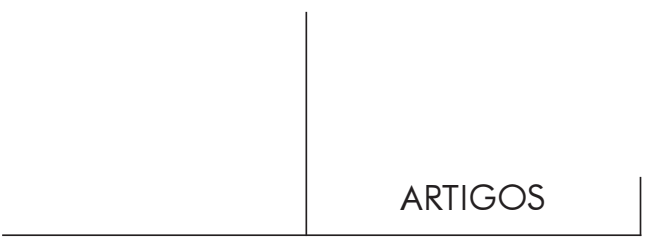

... a excitação sensual, apaixonada mesmo, que dele se desprendia, me fez concluir que ia ser importante, no trabalho futuro, que eu tentasse manter o clima analítico e interpretasse, se quisesse vê-lo conseguir, gradualmente, distinguir-se de suas ilusões primitivas e ajudá-lo, dessa forma, a chegar a um acordo com os sentimentos provocados pela desilusão. (...) tentava formular minhas interpretações de modo tão simples quanto possível, usando sempre as poucas palavras que os pais me tinham dito que ele talvez conseguisse entender... (ibid.: 11).

Quanto ao caso de Dick, Klein explicou:

Eu modifiquei minha técnica habitual. Em geral, não interpreto os dados obtidos até que estes não se hajam expressado através de várias representações, mas, neste caso, em que a capacidade de expressão por meio de representações quase não existia, fui obrigada a fazer minhas interpretações à base do meu conhecimento geral, pois na conduta de Dick, as representações eram relativamente vagas (Klein, 1930: 308).

Essas passagens mostram Klein, Tustin e Laznik-Penot considerando o lugar do psicanalista como aquele do intérprete ou do tradutor, mesmo na ausência do brincar, das associações livres, das fantasias e da relação transferencial das crianças analisadas (Dick, John e Halil). Nesses casos, apesar das modificações da técnica primordial, realizadas por Tustin (interpretação das "figuras de sensação", no lugar da interpretação do jogo) e por Laznik-Penot ("tradução", no lugar da interpretação da palavra), o princípio básico da técnica psicanalítica permaneceu inalterado: houve o uso da interpretação desde o início do tratamento da criança autista.

Ao considerar o material clínico trazido por Maria como sendo de outra natureza - diferente da natureza simbólica, conferida por Klein, no caso de Dick, e por Tustin, no caso de John, como também distinto do material pré-simbólico, traduzido por Laznik-Penot -, pude me situar em um outro lugar, o de psicanalista não intérprete. Ou seja, parti, desde o início, com a observação de que o material clínico apresentado por Maria era de outra natureza, não passível de ser nomeado, de pronto, pelo psicanalista.

Os momentos em que Maria começava a "grunhir" e fazer "maneirismos" parecia estar hipnotizada pelo movimento das próprias mãos, em frente ao rosto, como também embevecida pelos próprios sons - eram especiais, muito distintos dos outros comportamentos de Maria, como o de correr de um lado para outro, jogar objetos pelo chão, abrir e fechar a torneira do banheiro etc. Nesses momentos hipnóticos, Maria se apresentava "viva”, no sentido de haver uma exteriorização singular de "grunhidos e maneirismos", uma forma de apresentação direta, não mediada pela palavra. Nessa forma direta de apresentação, Maria podia ser ouvida e reconhecida como uma criança impossibilitada de pensar em suas angústias, fantasiar, falar ou brincar. 
A partir do lugar de analista não intérprete e apostando na singularidade de Maria com sua forma direta de se apresentar, teve início o seu tratamento psicanalítico, assim ocorrido: os "grunhidos e maneirismos" surgiam repetitivamente nas sessões. Eu procurava vivenciá-los nos momentos em que ela parecia hipnotizada por si mesma. Tentava me fazer presente, repetindo os sons que ela produzia, deixando em suspenso os significados que me vinham à mente. Mas não conseguia "grunhir" como Maria. Os sons que saíam de minha boca eram diferentes e não me permitiam comunicar com ela, levando-me a experimentar uma sensação de profundo isolamento. Essa vivência de isolamento foi extremamente valiosa, ao me possibilitar experimentar o meu próprio corpo na presença de Maria. Havia um isolamento preenchido por sensações anárquicas, esmaecidas, imprevisíveis e não nomeáveis. Ao ser levada por essas sensações, tornou-se mais fácil deixar em suspenso os significados dos sons e gestos de Maria.

Durante essa fase inicial do tratamento, mesmo sem estar em sessão com Maria, eu me lembrava inesperadamente dela ao fazer determinados movimentos espontâneos com o meu próprio corpo. Era como se Maria estivesse presente naqueles movimentos. Eram movimentos que vinham do meu corpo e eram reconhecidos, por mim, como sendo parecidos com os de Maria. Era a natureza sensorial da relação com Maria exteriorizando-se...

Como foi descrito na apresentação do caso de Maria, no momento em que eu comecei a repetir os sons de seus "grunhidos", ela começou, pouco a pouco, a se dirigir ao meu corpo. Primeiramente, para a boca e o pescoço e depois para os olhos, na troca de olhares. No instante em que Maria começou a tocar meus lábios e minha garganta, surgiram os primeiros sinais de angústia e uma seqüência previsível de comportamentos. Por exemplo, ela chegava ao consultório, jogava alguns brinquedos no chão, corria pela sala e depois começava a "grunhir", esboçando um jogo incipiente de sons. Ela emitia os sons, ficava calada olhando para as paredes, depois olhava para minha boca. Nesse momento, eu emitia os sons e ela recomeçava a seqüência.

Os sinais de angústia começaram a aparecer no período de espera, em que ela interrompia a emissão dos sons e olhava para minha boca. Diante da frágil capacidade de espera em Maria, comecei a imaginar as razões do surgimento de sua angústia. Nesse contexto, as interpretações se fizeram presentes, para tentar impedir que Maria rompesse, com ataques violentos de angústia, o jogo dos balbucios, que já então acontecia.

As primeiras interpretações dirigidas a Maria foram, na realidade, descrições de suas sensações. Por exemplo, quando ela olhava aflita para a minha boca, à espera dos sons que queria ouvir, se por alguma razão não eram os sons que ela gostaria que estivessem lá, ela começava a bater a cabeça nas paredes do consultório, se mordia ou se dirigia desesperada em minha direção para me morder. Nesses mo- 


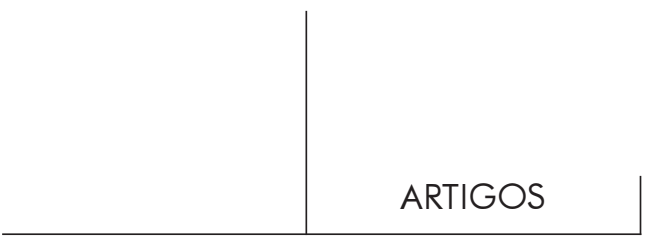

mentos, eu a segurava de costas para mim, e dizia: "eu continuo aqui com você". No início, ela se debatia muito, mas, com o tempo, ela passou a se aconchegar em meu colo. Muitas vezes, eu não dizia nada, apenas a segurava em meu colo, respirava calmamente, e quando sentia que ela estava calma e aconchegada em meus braços, começava a repetir os sons. Então ela recomeçava o jogo dos sons.

Depois de seguidas repetições do jogo dos sons, pude interpretar o estado de ansiedade de Maria, antes que ela interrompesse o jogo com o surgimento da angústia. Por exemplo, em determinados momentos, Maria, após um simples olhar para minha boca, já apresentava uma respiração ofegante e determinados maneirismos extremados. Então eu lhe dizia, antes de emitir os meus sons: "os meus sons nem sempre são os mesmos; você não pode controlar o que gosta de ouvir". As interpretações visavam permitir que Maria suportasse as desilusões da não continuidade corporal entre mim e ela.

Por meio do jogo dos sons, Maria vivenciou seu próprio corpo como uma "tempestade emocional", marcada por ataques violentos de angústia. A partir do momento em que comecei a reconhecer os sinais da "tempestade", me senti agindo como uma mãe que se identifica de forma empática com as necessidades de seu bebê, e pode conter seus ataques de tensão emocional, sem entrar em estado de descontrole emocional. As descrições do analista continente de Bion (1961) e Winnicott (1958) serviram, nesse momento, como base teórica para as interpretações.

Tustin e Laznik-Penot utilizaram, cada uma à sua maneira, a noção de "rêverie materna" definida por Bion: Tustin, para interpretar as sensações e Laznik-Penot, para traduzir para a mãe o sentido dos atos do filho, e assim devolver à mãe a capacidade descrita por Winnicott como a “... loucura necessária das mães”. Ou seja, para Laznik-Penot, o analista opera "na loucura de escutar uma significação, aí onde há apenas massa sonora, mas também direito exorbitante de escolher um sentido em detrimento de todos os outros possíveis" (1997: 21).

Como já mencionei no começo da minha experiência com Maria, não encontrei a possibilidade de interpretar a partir de uma relação íntima e empática com ela. No início do tratamento, eu não me sentia no lugar do analista continente-intérprete ou tradutor, tendo como paradigma a relação da mãe com o seu bebê. Eu apenas vivenciava sensações isoladas, que eram confusas e imprevisíveis, a ponto de não me permitir fazer ligações com Maria. Era uma situação de "estar em contato comigo mesma na presença de Maria”, sem capacidade para imaginar os sentidos das sensações dela e sem escutar uma significação. Talvez pela ausência de uma ligação primária entre mim e ela... Ou seja, era diferente de estar com um bebê, que pode ser sentido a partir de um contato corporal íntimo e responsivo (a mãe junto ao seu bebê pode sentir o ritmo das mamadas, ver o sorriso e sentir o aconchego do corpo do bebê em seu corpo, escutar as batidas ritmadas do seu coração, ouvir a sua respiração, perceber as diferenças do choro - se é de fome, dor ou manha -, olhar 


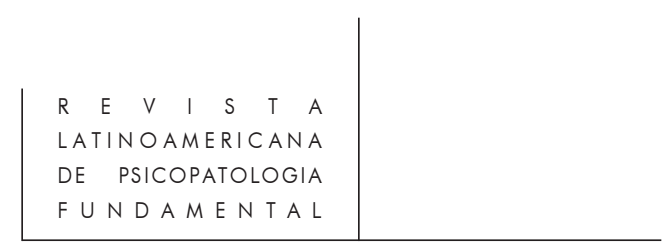

e se sentir olhada, sorrir para ele e ver o sorriso nos seus lábios, apesar de saber que se trata de um reflexo neurológico...) Em suma, essas vivências íntimas, corporais e emocionais, que a mãe tem com o seu bebê, permitem a ela imaginar e interpretar as necessidades e desejos do bebê. A mãe, ao interpretar os estados emocionais do bebê, lhe designa um lugar no reino da linguagem. Porém, a interpretação só se faz presente a partir de uma relação empática da mãe com o seu bebê.

Com Maria, o ponto de partida não era o mesmo da relação da mãe com o seu bebê: faltava a relação íntima de empatia, por meio da qual eu poderia dar sentido aos seus "grunhidos e maneirismos".

No princípio, também não havia como tocá-la ou ser tocada por ela. Assim, eu não podia sentir o seu corpo, não podia olhar seus olhos, não me sentia olhada por ela e não podia distinguir os "grunhidos" de fome ou a expressão de alguma outra sensação. Eu me sentia impossibilitada de imaginar qualquer forma de expressão de afeto ou necessidade em Maria. Ou seja, no início do tratamento de Maria, não era possível para mim ser continente, do mesmo modo que a mãe o é com o seu bebê. A mãe pode conter em si mesma os estados emocionais aflitivos do bebê e transformá-los em palavras. Ao fazer isso, a mãe introduz o bebê no reino da linguagem.

142 Possivelmente, eu apenas tivesse a possibilidade de conter as angústias impensáveis de Maria, e de me manter em contato com as minhas sensações confusas, sem me desesperar com a impossibilidade de traduzi-las. Nesse sentido, eu estaria ocupando apenas a posição de analista continente, que não tem palavras para interpretar e traduzir para o paciente. Eu me oferecia apenas como presença corporal e psíquica, e não como intérprete. Como já mencionado, a condição de analista continente-intérprete, descrita por Bion e Winnicott, só começou a surgir no trabalho com Maria ao serem identificados os primeiros sinais de angústia no contexto do jogo dos sons.

Dessa rica e singular experiência com Maria, surgem duas perguntas fundamentais para uma posterior exploração: seria possível enquadrar no âmbito psicanalítico esse primeiro encontro com Maria, marcado por vivências não passíveis de interpretação ou tradução? seria possível, aí, "ouvir" os fenômenos intraduzíveis da constituição de "si mesmo"?

A imagem que me veio à mente, no primeiro dia que vi Maria e seus pais, talvez possa ser uma pista para responder a essas questões: ao balançar as mãos e correr na ponta dos pés, Maria dava a impressão de flutuar no ar. Seus movimentos pareciam com os de um beija-flor, quando fica parado no ar para "beijar" as flores. A beleza do corpo de Maria me deixou emocionada e minha visão foi de contemplação, ou seja, tive uma imagem bonita, diferente por completo da dos pais (eles consideravam os maneirismos dela como um sinal da doença, um comporta- 


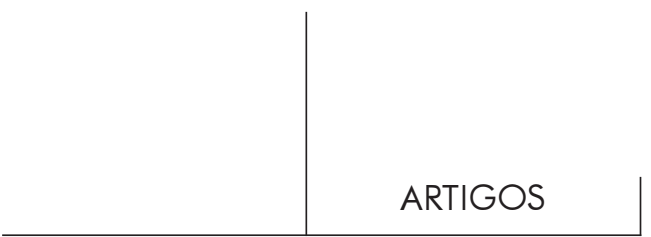

mento vergonhoso e inaceitável). Esse tipo de encontro, marcado por uma contemplação inicial positiva, foi espontâneo e inesperado.

Talvez essa contemplação imaginária positiva possa traduzir um tipo de encontro que é eminentemente fenomenal e estético, como diz Julia Kristeva (1996), ao falar de uma clínica psicanalítica não marcada pela necessidade de reduzir experiências inomináveis em significantes puros, o que acabaria com a capacidade perceptiva e sensorial do analista diante da tendência permanente de interpretar. $A i ́$ se encontra, provavelmente, uma outra questão fundamental que pode ocorrer no início da relação psicanalítica com uma criança autista, extraída do caso de Maria: um início marcado pela escuta do inominável.

Em conclusão, o ponto central do artigo, essa nova forma de se iniciar o tratamento psicanalítico com crianças autistas, que não falam e não brincam, pode e deve ser discutida, não apenas em comparação com outros casos clínicos, mas à luz dos princípios das principais escolas psicanalíticas. Em um outro espaço, obviamente.

\section{Referências Bibliográficas}

Alvarez, A. Companhia viva: psicoterapia psicanalítica com crianças autistas, "borderline”, carentes e maltratadas. Porto Alegre: Artes Médicas, 1994.

Bion, W. R. The psychoanalytical study of thinking. In Int. J. Psycho-Anal., 43, p. 306-310, 1962.

Dolto, F. Cure psycahnalytique à l'aide de la poupée-fleur. In Revue française de Psychanalyse, XIV, n. 1, janvier-mars, 1950.

Ferro, A. L'enfant et le psychanalyste. Paris: Erès, 1997. Seminário de psicoanálisis de ninõs. $3^{\circledR}$ ed. México: Siglo Veintiuno, 1987.

Freud, S. (1895) Projeto para uma psicologia científica. In ESB. Rio de Janeiro: Imago, 1976. v. 1.

Freud, S.-Pfister, O. Correspondência 1909-1939. México-Buenos Aires: Fondo de Cultura Económica, 1966.

Houzel, D. Thinkings: a dialetic process between emotions and sensations. In Enconunters with Autistic States. Londres: Jason Aronson Inc., 1991.

KANNER, L. Autistic disturbance of affective contact. Nervous Child, 2, p. 217-250, 1942.

Kristeva, J. A sensação é uma linguagem. IDE, julho de 1996, n. 28.

KLEIN, M. (1921-1945). Les principes psychologiques de l'analyse des jeunes enfants. In Contributions to Psychoanalysis. Londres: The Hogarth Press, 1948. La psychanalyse des enfants. Paris: PUF, 1932.

La technique de jeu psychanalytique: son histoire et as portée. In Lê transfert et autres écrits. Paris: PUF, 1995. p. 25-50. 


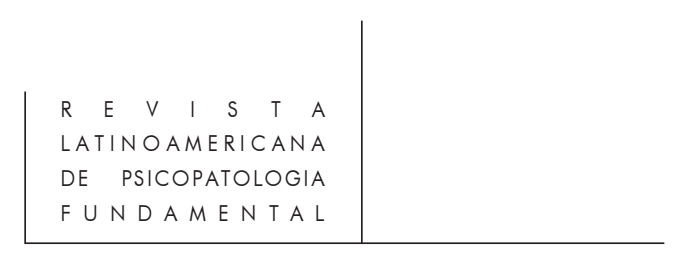

(1930). L'importance de la formation du symbole dans le développement du moi. In Essais de psychanalyse. Paris: Payot, 1980. p. 263-278.

LANGer, S. Filosofia em nova chave. 2a ed. São Paulo: Perspectiva, 1989. . Sentimento e forma. São Paulo: Perspectiva, 1980.

LAZnIK-PEnOt, M.-C. Rumo à palavra: três crianças autistas em psicanálise. São Paulo: Escuta, 1997.

Mannoni, M. L'enfant arriére et sa mère. Paris: Seuil, 1964. . L'enfant sa "maladie"et les autres. Paris: Seuil, 1967. . Un lieu pour vivre. Paris: Seuil, 1976.

Meltzer,O.; Hoxter, S.; Weddell, D., and Wittenberg, I. Explorations in Autism. A Psychoanalytical Study. Perthshire, Scotland: Clunie Press, 1975.

Rezende, A. M. Bion e o futuro da psicanálise. Campinas: Papirus, 1995.

SegAL, H. Introdução à obra de Melanie Klein. Rio de Janeiro: Imago, 1973.

Tustin, F. (1972). Autismo e psicose infantil. Rio de Janeiro: Imago, 1975.

Estados autísticos em crianças. Rio de Janeiro: Imago, 1984.

Contours autistiques et pathologie adulte. Topique, 35-36, p. 9-24, 1985.

El cascarón protector en niños y adultos. Buenos Aires: Amorrortu, 1990.

Revised understandings of psychogenic autism. International Journal of Psycho-Analysis, 72, p. 585-591, 1991.

The perpetuation of an error. Journal of Child Psychotherapy, 20 1, p. 3-23, 1994.

WinnicotT, D.W. A criança e o seu mundo. Rio de Janeiro: Zahar, 1979.

\section{Resumos}

Este artículo discute el inicio de la relación analítica con niños autistas a la luz del análisis de María, una niña autista de 3 años de edad. Este caso clínico se volvió importante como objeto de estudio, por haber suscitado un cuestionamiento de los principios teórico-clínicos que inducen al psicoanalista a encontrar significados en las acciones de un niño autista, aunque éste no hable ni juegue, y a interpretarlos, desde el comienzo de uma relación analítica, con la intención de crear la relación transferencial.

Con María, la analista, al comienzo del tratamiento, dejó en suspenso los significados y las interpretaciones y pasó a vivenciar la natureza fenoménica de los "gruñidos" y "manierismos" de la niña. Al proceder de esta manera, se abrió otra vía para crear uma relación analítica con María: las diversas tonalidades de sus "gruñidos", el zumbido de sus "manierismos", las formas de sus movimientos corporales y el ritmo de su respiración pasaron a ser contenidos por la analista, sin la necesidad imperiosa de interpretar.

Palabras llave: Psicoanálisis, autismo, significación, interpretación 


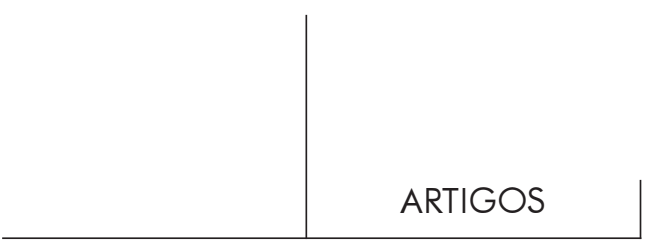

Cet article examine le début du traitement psychanalytique avec des enfants autistes, à la lumière de l'analyse de Maria, un enfant autiste de trois ans. Ce cas clinique est devenu un important objet d'étude, introduisantn un questionnement des modèles théoriques-cliniques existants, dans lesquels l'analyste utilise l'interprétation comme un outil indispensable à la création de la relation transférentielle avec l'enfant autiste qui ne parle pas et ne joue pas.

Avec Maria, l'analyste, au debút du traitement, a pu vivre la possibilité de ne pas nommer les possibles significations des grognements, il a pu être plus en contact avec son propre corps. Les actions psychanalytiques du début employées par l'analyste ont été celles de voir, d'écouter et de sentir son propre corps en présence de Maria lors des séances, en mettant de côté le besoin impérieux d'interpréter. Cette attitude l'a conduite à d'autres moyens d'être avec Maria en tenant compte des différentes tonalités des "grognements" de l'enfant, du bruit de ses "maniérismes", du rythme de sa respiration et des mouvements de son corps, en mettant de côté le besoin impérieux d'interpréter.

Mots clés: Psychanalyse, autism, signification, interpretation

This article discusses the beginning of an analytical relationship with autistic children, based on Maria's analysis, a three years old autistic child. The clinic case of Maria has became important as an object of study, for had given rise to an argue about the theoretical-clinic principles that make a psychoanalyst to find meaning on autistic child's actions, even when she doesn't talk and play, and to interpret them, from the beginning of an analytical relationship, as an effort to create the transferential relationship.

With Maria, the analyst, in the beginning of the treatment, put the meanings and the interpretations way and started to live the phenomenal nature of the child's "grunts" and "gestures". Acting like that, another way was opened to create an analytical relationship with Maria: the several tones and rhythms of her "grunts", the buzz of her "gestures", the shapes and movements of her body and the rhythm of her breathing, were held by the analyst in her own body, however, without the classical interpretation of these clinical material.

Key words: Psychoanalysis, autism, meaning, interpretations

Versão inicial recebida em julho de 2000.

Versão revisada recebida em novembro de 2000. 